\title{
Comportamiento del virus de la bronquitis infecciosa aviar en aves con sintomatología respiratoria provenientes de granjasdeproduccióndelDepartamentodeCundinamarca
}

\author{
Avian Infectious Bronchitis virus behavior in birds from commercial \\ farms with a history of respiratory disease, located in the department of \\ Cundinamarca
}

Geovanna Córdoba Argoti ${ }^{1-2}$, Victor Julio Vera Alfonso ${ }^{1}$, Jairo Correa Jaime ${ }^{1}$. ${ }^{*}$ Gloria Consuelo Ramírez-Nieto ${ }^{1}$

\section{Resúmen}

Objetivo. Evaluar la dinámica serológica contra el virus de la bronquitis infecciosa aviar y su relación con la presentación y/o antecedentes de signos clínicos y hallazgos patológicos, bajo condiciones de campo. Materiales y métodos. Se realizó un muestreo al azar en dos fases, en pollo de engorde y reproductoras de granjas del Departamento de Cundinamarca. En la primera fase se tomó muestra de sangre a un total de 224 aves, distribuidas en 7 granjas. En la segunda fase, realizada 20 días posteriores al primer muestreo, se tomó una segunda muestra al mismo número de aves empleadas inicialmente. Las muestras de los sueros obtenidos se emplearon para la realización del inmunoensayo ligado a enzima (ELISA), diseñado para detectar anticuerpos frente al virus de la bronquitis infecciosa aviar en suero sanguíneo. Resultados. Se obtuvo que del total de las granjas analizadas el $85.72 \%$ mostró reactividad serológica al virus de la Bronquitis Infecciosa aviar (VBIA), mostrando correlación con la presencia de los signos clínicos o antecedentes respiratorios en granja.

Palabras Clave. BIA, Prueba de Elisa, Anticuerpos, Serología.

\begin{abstract}
Objective. To evaluate the serological dynamics against avian infectious bronchitis virus and its relationship with the presentation and / or a history of clinical signs and pathological findings, under field conditions. Materials and methods. A random sampling was conducted in two phases, in broiler and breeder farms located in the Department of Cundinamarca. In the first phase blood samples were taken from a total of 224 birds, distributed over the 7 farms. In the second phase, carried out 20 days after the first, a second sample was collected from the same number of birds used in the first phase. The serum samples were used to carry out the enzyme linked immunoassay (ELISA) intended to detect antibodies against avian infectious bronchitis virus in blood serum. Results. As a result it was found that from the total farms analyzed the $85.72 \%$ showed serologic reactivity against Avian Infectious Bronchitis Virus (AIBV) and that this was correlated to the presence of clinical signs or previous history of respiratory disease in the farm.
\end{abstract}

Keywords: BIA, ELISA, antibodies, serology.

${ }^{1}$ Grupo de investigación en Microbiología y Epidemiología. FMVZ, Universidad Nacional de Colombia, Bogotá 20RCID: 0003-1197-8998

Correspondencia: gcramirezn@gmail.com

Recibido: 11/03/2015 Aceptado: 29/05/2015 


\section{Introducción}

La infección con virus de bronquitis infecciosa aviar (VBIA) ocasiona uno de los problemas respiratorios virales en aves más difíciles de controlar en muchas partes del mundo. La presencia de nuevas variantes del virus circulando entre las aves (1), como resultado de mutaciones espontáneas o de recombinaciones genéticas del virus representa una amenaza importante aún en explotaciones de aves inmunizadas (2). El impacto económico de la BIA se relaciona con que tiene un efecto negativo en la ganancia de peso, afecta la eficiencia alimenticia, ocasiona alteraciones en la producción y calidad del huevo, a menudo favorece la presencia de infecciones mixtas, llevando a pérdidas incluso en el producto terminado por decomisos al momento del sacrificio (3).

El virus causante de la Bronquitis Infecciosa aviar (VBIA), pertenece al género Coronavirus, de la familia Coronaviridae, y el orden Nidovirales (4), el cual se ha clasificado en el grupo 3 basados en la antigenicidad, organización del genoma, y similitud de su secuencia (5). El virus tiene morfología pleomórfica esférica, su diámetro varía entre los 90 a $200 \mathrm{~nm}$, tiene envoltura lipídica y proyecciones superficiales llamadas espículas que le dan forma de corona (6). Su genoma se compone de ARN de cadena sencilla y polaridad positiva (7); compuesto por aproximadamente 27.500 nucleótidos dispuestos en una hebra que codifica para cuatro proteínas estructurales, la proteína de las proyecciones de la superficie (S), que a su vez está compuesta por dos subunidades: la glicoproteína de espiga (S1) y el sobre pequeño (S2) de proteínas, la glicoproteína de membrana $(\mathrm{M})$ y la proteína de la nucleocápside $(\mathrm{N})(8,9)$, Figura 1.

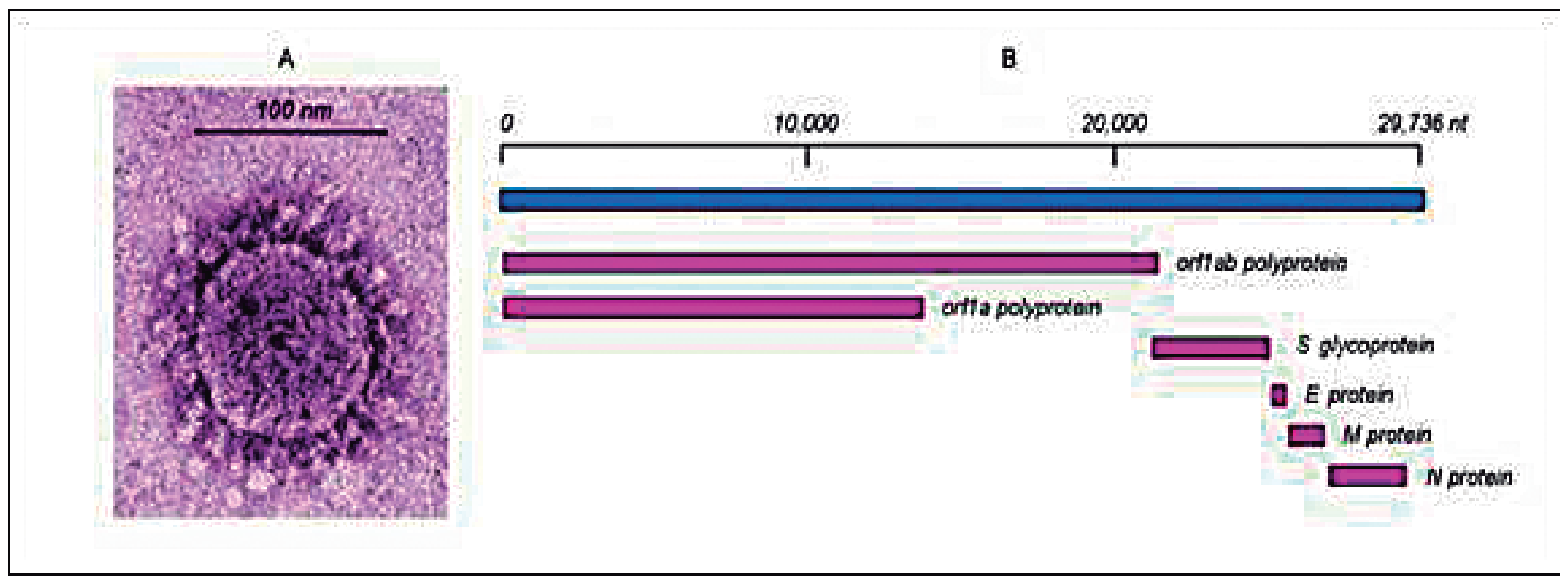

Figura 1. Estructura del coronavirus - VBIA. (A) Microscopia electrónica mostrando un virus pleomórfico de diámetro entre 90 y 200nm,que presenta una envoltura lipídica y estructuras que sobresalen dándole apariencia de corona (B) Representación esquemática del ARNm que codifica para las proteínas virales (37).

El principal sitio de replicación del virus de la BIA es el tracto respiratorio superior, a partir del cual se disemina logrando replicarse también en tejido del tracto intestinal, riñones y el oviducto, así como en la glándula de Harder después de una inoculación ocular. La en- fermedad es altamente contagiosa, se transmite de forma horizontal y su período de incubación va de 18-36 horas (8-10), su diseminación es de curso rápido dependiendo de la ruta de inoculación y los signos clínicos se evidencian de 24-48 horas posteriores al inicio de la infección (11). 
El virus de la BIA puede persistir o permanecer contaminando por aproximadamente 4 semanas. Las aves se vuelven transportadoras y diseminadoras de la enfermedad (7).

La sintomatología de la enfermedad es variable y depende de factores tales como la cepa de virus infectante, la edad y el estado inmunitario de las aves $(12,13)$. La morbilidad es generalmente alta, $100 \%$ en la mayoría de los casos, pero la mortalidad frecuentemente es baja (5\%) (12-14). El cuadro clínico de tipo respiratorio se caracteriza por ser de curso agudo, ocasionando dificultad para respirar, estornudos, tos, descargas nasales y oculares. Las aves infectadas tienen una pobre ganancia de peso y una rápida disminución en la producción y calidad de los huevos. La forma de presentación renal se relaciona con el síndrome de nefritis y nefrosis (15).

El diagnóstico de la BIA generalmente se basa en la historia clínica, la detección del antígeno, el aislamiento viral, o los resultados de pruebas como Elisa, aglutinación rápida en placa, inmunofluorescencia e inmunoperoxidasa $(13,14)$. La evaluación serológica se realiza a través de pruebas de neutralización viral, Elisa indirecto e inhibición de hemaglutinación. La detección del genoma viral la realiza a través de RT-PCR y qRT-PCR (16), y la secuenciación de nucleótidos se emplea para identificar y caracterizar las diferentes cepas del virus (17).

Las pruebas serológicas permiten evaluar los títulos de anticuerpos, posterior a procesos vacunales y ante desafíos de campo (4). Entre las pruebas más comunes se encuentra el inmunoensayo asociado a enzimas para captura de antígeno (AC-Elisa, por su sigla en inglés), siendo una prueba de unión primaria que detecta el enlace específico antígeno - anticuerpo y cuantifica los inmunocomplejos formados, su fundamento es el empleo de enzimas para detectar éstas uniones (18). Una limitante de la prueba de Elisa es que no permite diferenciar entre un serotipo y otro del virus (19), para tal caso existen otras técnicas como la neutralización viral e HI (20). La prueba de Elisa se utiliza para detectar la respuesta de anticuerpos y permite establecer relaciones comparativas de resultados obtenidos hasta 2-3 semanas post infección (21) siendo ampliamente utilizada para identificar poblaciones infectadas por el virus de BIA y respuesta de anticuerpos como resultado de programas vacunales contra el virus de la BIA (22). Es una prueba de fácil uso, además su sensibilidad permite detección de anticuerpos tipo Inmunoglobulina $\mathrm{G}$ ( $\mathrm{IgG}$ ), aún a niveles muy bajos $(18,23)$. Los resultados de la lectura de la densidad óptica se clasifican en grupos o perfiles en un histograma (24), tales resultados deben ser correlacionados dentro del comportamiento de los sueros a través de valores máximos y mínimos y el coeficiente de variación, ya que esto refleja la uniformidad de los resultados (25).

En nuestro medio, a pesar de la implementación de esquemas vacunales dirigidos hacia el control del virus de la BIA y de la aplicación de tratamientos contra problemas respiratorios, se siguen presentando brotes en lotes de producción avícola, con implicaciones de sintomatología respiratoria de difícil tratamiento y con cuadros clínicos compatibles con la enfermedad producida por el virus de la BIA, que afectan el ciclo productivo de las parvadas. Por tanto es necesario el desarrollo de estudios que aporten al conocimiento del comportamiento del virus de la BIA en granjas con afección respiratoria. Para tal fin el presente estudio busca determinar el comportamiento de anticuerpos contra el VBIA y relacionarlo con los hallazgos clínicos y/o antecedentes de vacunación del lote muestreado contra el virus de Bronquitis infecciosa aviar en aves de producción bajo condiciones de campo, mediante el uso de una técnica de detección de anticuerpos $(\mathrm{IgG})$, tipo Elisa indirecta a través del kit FlockChek ${ }^{\oplus}$ (Infectious Bronchitis Virus Antibody Test Kit del fabricante IDEXX Laboratory, Inc., Westbrook, ME.) 


\section{Materiales y métodos}

Se seleccionaron aves con sintomatología respiratoria provenientes de 6 granjas de pollos de engorde y 1 granja de ponedoras, ubicadas en el Departamento de Cundinamarca, las cuales presentaban antecedentes de problemas respiratorios.

Se realizó un muestreo al azar, empleando un total de 224 aves a las cuales se les tomó muestra de sangre para la detección de anticuerpos contra el virus de la BIA. Se realizaron dos muestreos en cada una de las granjas con un intervalo de 20 días entre el muestreo 1 y el muestreo 2. En la tabla 1 se relaciona cada una de las granjas empleadas para la obtención de sueros, la distribución del número de aves muestreadas, identificación de la granja, tipo de explotación y ubicación geográfica.

Tabla 1. Resumen de granjas empleadas y número de muestras obtenidas en cada muestreo.

\begin{tabular}{|c|c|c|c|c|c|}
\hline \multirow{2}{*}{ GRANJA } & \multirow{2}{*}{ UBICACION } & \multirow{2}{*}{$\begin{array}{l}\text { TIPO DE EX- } \\
\text { PLOTACION }\end{array}$} & \multicolumn{2}{|c|}{$\begin{array}{l}\text { No. DE AVES MUESTRA DE } \\
\text { SUERO }\end{array}$} & \multirow{2}{*}{$\begin{array}{l}\text { MUESTRAS } \\
\text { OBTENIDAS: Aves } \\
\text { con sintomatología } \\
\text { respiratoria }\end{array}$} \\
\hline & & & MUESTREO 1 & MUESTREO 2 & \\
\hline No. 1 SL. & La Mesa & Reproductoras & 35 & 35 & \multirow{8}{*}{$\begin{array}{c}\text { Hisopos traqueales, } \\
\text { Tejidos: } \\
\text { tráquea, } \\
\text { riñón, } \\
\text { pulmón, y } \\
\text { tonsilas cecales. } \\
\text { Colectados al momento } \\
\text { del Muestreo } 1\end{array}$} \\
\hline No. 2 L1 & Villeta & Engorde & 30 & 30 & \\
\hline No. 3 SR & Valle de Tenza & Engorde & 35 & 35 & \\
\hline No. 4 DN & Sopó & Engorde & 34 & 34 & \\
\hline No. 5 PN & Villeta & Engorde & 34 & 34 & \\
\hline No. 6 BQ & Ubaque & Engorde & 30 & 30 & \\
\hline No. 7 SC & Ubaque & Engorde & 26 & 26 & \\
\hline TOTAL & \multicolumn{2}{|c|}{7 Granjas } & 224 & 224 & \\
\hline
\end{tabular}

Las muestras obtenidas (riñones, tráqueas, pulmones, hisopos traqueales), fueron procesadas para el aislamiento e identificación del virus de BIA.
Plan vacunal aplicado por granja, para el control de la bronquitis infecciosa aviar

En la tabla 2 se presenta el esquema de vacunación dirigido hacia el virus de la BIA establecido en cada granja y edad al día de toma de las muestras. 
Tabla 2. Plan de vacunación de las granjas muestreadas.

\begin{tabular}{|c|c|c|c|c|}
\hline GRANJA & EDAD (Días) & CEPA & $\begin{array}{l}\text { EDAD TOMA DE } \\
\text { MUESTRA } 1 .\end{array}$ & $\begin{array}{c}\text { EDAD DÍA TOMA } \\
\text { DE MUESTRA } 2 .\end{array}$ \\
\hline \multirow{5}{*}{ No, 1 SL. } & 4 & Mas5 & \multirow{5}{*}{33 semanas } & \multirow{5}{*}{37 semanas } \\
\hline & 21 & $\mathrm{H} 120$ & & \\
\hline & 8 semanas & Mas5 & & \\
\hline & 18 semanas & Mas5 & & \\
\hline & Cada 8 semanas & Mas5 & & \\
\hline
\end{tabular}

5 H120

No. 2 L1

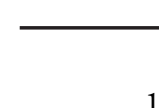

15

Mas5 Clone 30

No. 3 SR

14

Mas 5

29 días

46 días

$6 \quad$ M48

No. 4 DN

M48

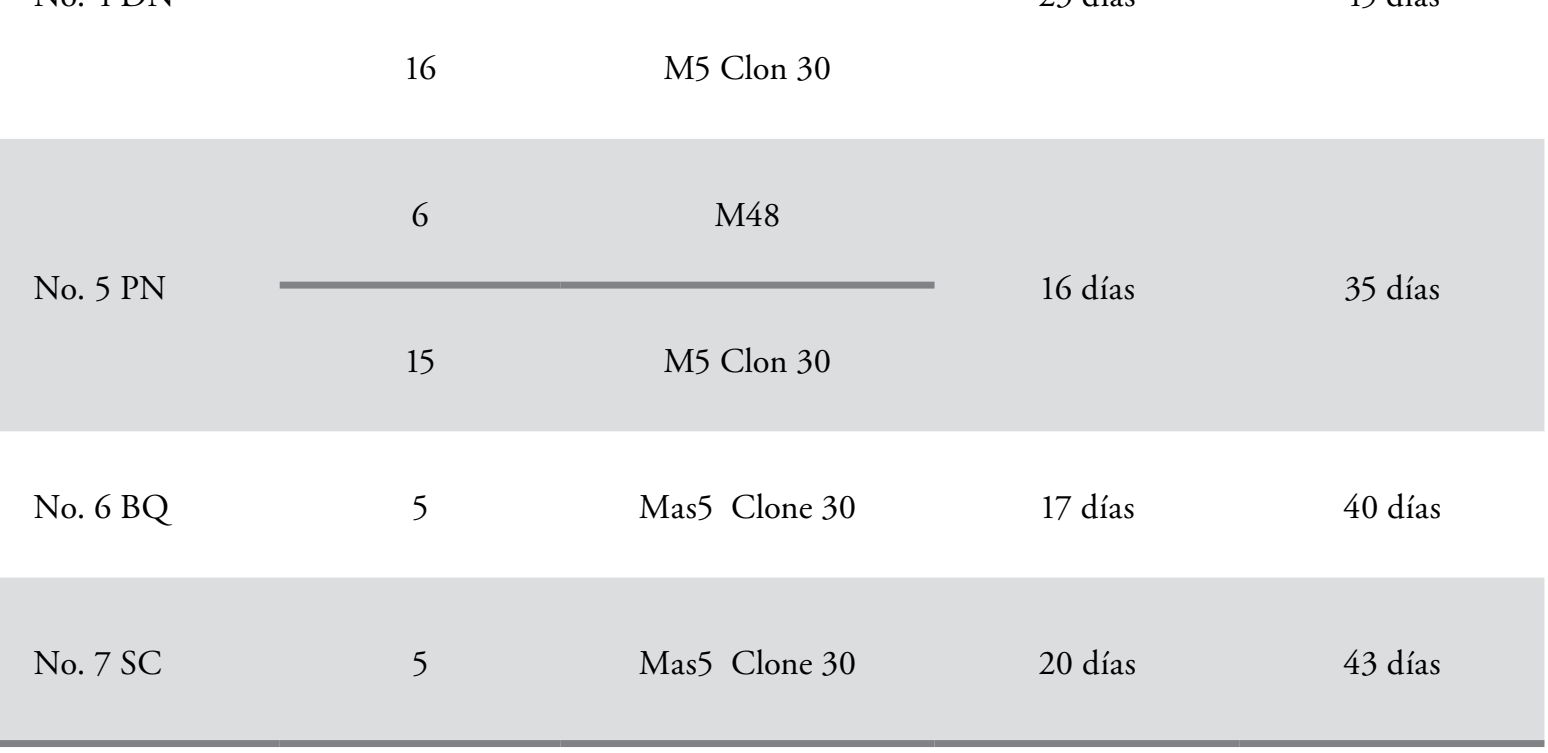




\section{Toma y procesamiento de las muestras}

Se tomó muestra de sangre por punción de la vena braquial, colectando un volumen de $1.5 \mathrm{ml}$ de sangre por ave muestreada en tubos eppendoft sin anticoagulante. Las muestras de sangre fueron transportadas al laboratorio de virología en donde se centrifugaron a $5.000 \mathrm{rpm}$ durante 3 a 5 minutos para obtener el suero sanguíneo.

Así mismo a éstas aves se les tomó muestras de tejidos de tráquea, riñón, pulmón, tonsilas cecales e hisopados traqueales, las cuales fueron procesadas en pooles de la siguiente manera: Se tomó un volumen de tejido para ser macerado en solución de PBS suplementado al 1\% con solución de antibiótico-antimicótico en proporción de 1:10 (tejido:PBS). El sobrenadante obtenido fue filtrado, y a partir del producto obtenido se inoculó un volumen de $200 \mu \mathrm{I}$ en la cavidad alantoidea de huevos embrionados SPF de 9-11 días de edad. Los huevos fueron incubados a una temperatura de $37^{\circ} \mathrm{C}$ por 72 horas para la obtención del líquido alantoideo y por 48 horas adicionales para la observación de cambios en el embrión. Se colectó el líquido alantoideo de los huevos inoculados el cual fue transferido a tubos estériles. Con las cosechas del líquido alantoideo obtenido se realizó la prueba de hemoaglutinación (HA). A aquellas muestras que resultaron positivas a la prueba de HA se les realizó el análisis por RT-PCR.

Para la prueba de RT-PCR se emplearon los primers UTR1 (GCTCTAACTCTATACTAGCCTAT) / UTR2 (GCTCTAACTCTATACTAGCCTAT), los cuales amplifican la región 3'UTR, y los primers IBV-LC5 (ACTGGCAATTTTTTCAGA) / IBV-LC3 (ACAGATTGCTTGCAACCAC), y XCE1 (ACTGGTAATTTTTCAGATGG) / XCE2 (CCTCTATAAACACCCTTACA) que amplifican una región del gen $S 1$ del virus de
BIA. Se empleó el kit RT-PCR Quiagen ${ }^{\circ}$ OnSteep RT-PCR Kit (Quiagen ${ }^{\circ}$ Cat No. 120212) y se llevó a cabo la amplificación bajo las siguientes condiciones: Denaturación inicial de $94^{\circ} \mathrm{C}$ por 5 minutos, 35 ciclos de $94^{\circ} \mathrm{C}$ por 1 minuto, $49^{\circ} \mathrm{C}$ por 1 minuto $72^{\circ} \mathrm{C}$ por 2 minutos y extensión final de $72^{\circ} \mathrm{C}$ por 7 minutos. Los productos obtenidos de la RT-PCR fueron analizados por electroforesis en gel de agarosa ultrapura al 2\% en buffer TAE $10 \mathrm{X}$ empleando GeneRuler 100 pb Plus ${ }^{\oplus}$ (Fermentas ${ }^{\oplus}$ ) como marcador de peso molecular.

\section{Detección de anticuerpos por la prueba de ELISA in-} directa

Se llevó a cabo la prueba de Elisa a cada uno de los sueros obtenidos, empleando el kit comercial FlockChek ${ }^{\oplus}$ Infectious Bronchitis Virus Antibody Test Kit (IDEXX Laboratory, Inc., Westbrook, $\mathrm{ME)}$. Las muestras fueron preparadas realizando una dilución de $1 \mu \mathrm{l}$ de la muestra en $500 \mu \mathrm{l}$ del diluyente, se incubó la placa durante 30 minutos a $18^{\circ} \mathrm{C}$ a $25^{\circ} \mathrm{C}$, se eliminó el contenido de la bandeja y se lavaron los pocillos con $350 \mu$ l de agua ultrapurificada. Se adicionó $100 \mu$ l del conjugado en cada pocillo y se incubó durante $30 \mathrm{~min}$ a una temperatura de $18^{\circ} \mathrm{C}$ a $26^{\circ} \mathrm{C}$, se eliminó el sobrenadante y se lavó nuevamente. Se adicionó el sustrato TMB en volumen de $100 \mu$ l en cada pocillo y se incubó durante 15 minutos a una temperatura de $18^{\circ} \mathrm{C}$ a $26^{\circ} \mathrm{C}$, transcurrido éste tiempo se adicionó $100 \mu \mathrm{l}$ de solución de parada en cada pocillo. Se realizó la lectura a una longitud de onda de 650nm (Protocolo del fabricante IDEXX).

\section{Parámetros de referencia para la lectura de la prueba de ELISA indirecta}

Para la interpretación de los resultados serológicos obtenidos se empleó como línea base los parámetros preestablecidos de títulos de anticuerpos de acuerdo a 
las recomendaciones del laboratorio fabricante del kit empleado (Laboratorios IDEXX), al igual que el reporte al que hacen referencia diferentes autores, por tanto se tomaron en cuenta los siguientes parámetros para interpretación de títulos de anticuerpos de manera general:

- Aves sin vacunación con títulos superiores a 690 son consideradas de exposición positiva al virus de la bronquitis infecciosa aviar.

- Aves con vacunación se consideran con exposición positiva cuando sus títulos son mayores a 2.000 .

\section{Análisis estadístico}

Los títulos de anticuerpos de los grupos experimentales se evaluaron realizando un soporte estadístico por la prueba de distribución de T-Student, para lo cual se plantearon dos Hipótesis (Hipótesis nula - "Ho", e Hipótesis alterna - "Ha") y se rechaza la Ho que plantea la no exposición al virus de campo interpretado a partir del nivel de anticuerpos obtenidos, y aceptando la Ha la cual plantea presentación del virus de campo a través de la obtención de valores de títulos de anticuerpos incrementados a partir de los valores esperados.

Ho: No se desarrollan anticuerpos a niveles que representen respuesta a exposición de virus de campo o virus vacunal.

Ha: Se desarrollan anticuerpos a niveles que representen respuesta a exposición de virus de campo o virus vacunal.

Se rechaza $H o$, si $\mathrm{Z}$ calculado es mayor que el $\mathrm{Z}$ critico de tabla (1.96) y por tanto se acepta la Ha, indicando la significancia estadística.

\section{Resultados}

En la tabla 3 se resumen los valores obtenidos en la prueba de Elisa y se puede observar la distribución de los grupos de acuerdo al rango de títulos de anticuerpos para cada una de las granjas y para cada muestreo, a la vez que se relaciona la media, el coeficiente de variación (CV\%) como medida de dispersión de cada uno de los conjuntos de datos, el cual está asociado a la desviación estándar del conjunto y su media aritmética y se obtiene en términos de porcentaje. Adicionalmente en la tabla se reporta el número de muestras de cada una de las granjas por muestreo realizado. Al analizar los resultados por granja se encontró que el $85.72 \%$ mostró positividad al virus de BIA, ya sea dada por presencia de virus vacunal o de campo.

Los resultados agrupados por grupos de títulos se graficaron en histogramas en los cuales, en el eje horizontal se ubica la barra de acuerdo al grupo que le corresponde $(0,1,2,3 \ldots$ etc.), y en el eje vertical se ubica la cantidad de aves. Cada barra en el histograma, representa la cantidad de aves con títulos dentro de un rango determinado. Los grupos de distribución van de 1 a 18, cada uno con un rango de títulos mínimo y máximo, que van desde valores de 0 hasta $>30.000$.

En la Grafica 1 se puede observar de manera comparativa, para cada una de las granjas evaluadas, la dinámica de presentación de los títulos de anticuerpos obtenidos en el primer muestreo correspondiente al día en que se presentaron síntomas respiratorios, comparados con los resultados del muestreo dos, realizado posteriormente a los 20 días, permitiendo apreciar la variación de títulos entre el muestreo $1 \mathrm{y}$ muestreo 2 . 
Tabla 3. Relación de resultados consolidados de \%CV y distribución de títulos de anticuerpos en cada una de las granjas.

\begin{tabular}{|c|c|c|c|c|c|c|c|c|c|c|c|c|c|c|}
\hline \multirow{3}{*}{$\frac{\ddot{8}}{8}$} & \multicolumn{14}{|c|}{$\begin{array}{l}\text { TABLA COMPARATIVA ENTRE \% DE COEFICIENTE DE VARIACIÓN Y MEDIA DE } \\
\text { TITULOS }(\mu \mathrm{g} / \mathrm{ml}) \text { DE ANTICUERPOS EN CADA DE UNA DE LAS GRANJAS. }\end{array}$} \\
\hline & \multicolumn{2}{|c|}{ No. 1 SL. } & \multicolumn{2}{|c|}{ No. 2 L1 } & \multicolumn{2}{|c|}{ No. 3 SR } & \multicolumn{2}{|c|}{ No. 4 DN } & \multicolumn{2}{|c|}{ No. 5 PN } & \multicolumn{2}{|c|}{ No. 6 BQ } & \multicolumn{2}{|c|}{ No. 7 SC } \\
\hline & 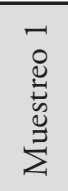 & 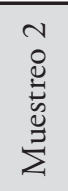 & 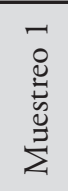 & 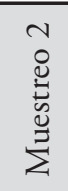 & 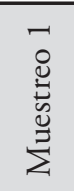 & 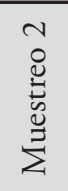 & 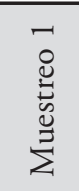 & 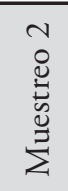 & 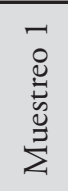 & 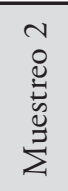 & 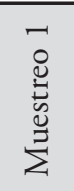 & 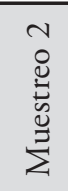 & 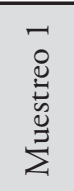 & 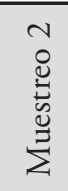 \\
\hline $\begin{array}{l}\text { Media (Titulo } \\
\text { Anticuerpos) }\end{array}$ & 5779 & 7720 & 3258 & 1379 & 2484 & 3949 & 954 & 1242 & 4945 & 5947 & 2668 & 3825 & 28 & 600 \\
\hline CV\% & 45.6 & 44 & 77.4 & 91.5 & 149.2 & 48.6 & 124.3 & 76.4 & 48.9 & 39.7 & 62.4 & 47.7 & 161.6 & 213.7 \\
\hline
\end{tabular}

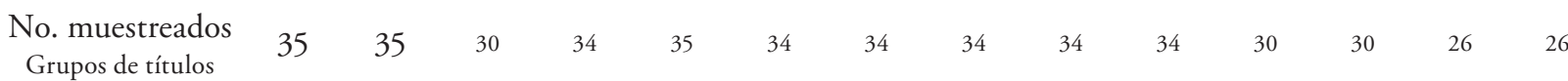

$\begin{array}{ccccccccccccccccc}0 & 0-400 & 0 & 0 & 1 & 8 & 8 & 0 & 18 & 5 & 0 & 0 & 1 & 1 & 26 & 21 \\ 1 & 401-1000 & 1 & 0 & 3 & 10 & 7 & 3 & 6 & 10 & 0 & 0 & 5 & 0 & 0 & 2 \\ 2 & 1001-2000 & 2 & 0 & 8 & 6 & 9 & 4 & 4 & 12 & 4 & 3 & 6 & 3 & 0 & 1\end{array}$

$3 \quad 2001-3000 \quad 3$

$4 \quad 3001-4000$

$\begin{array}{lllllll}5 & 4001-5000 & 9 & 2 & 3 & 2 & 4\end{array}$

$\begin{array}{llllllllll}6 & 5001-6000 & 3 & 3 & 1 & 0 & 1 & 7 & 0 & 0\end{array}$

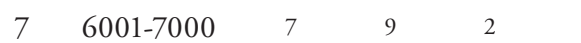

$8 \quad 7001-8000$

$9 \quad 8001-9000 \quad 3 \quad 4 \quad 0$

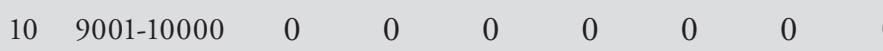

$11 \quad 10001-11000 \quad 0 \quad 2 \quad 0 \quad 0000$

12 11001-12000 $0 \quad 1 \quad \begin{array}{llllllllllllll}0 & 0 & 1 & 0 & 0 & 0 & 0 & 0 & 0 & 0 & 0\end{array}$


Para todas las granjas, de manera paralela en estudios adicionales desarrollados, se obtuvieron resultados positivos a través de pruebas como técnica de Hemoaglutinación (HA) y pruebas de RT-PCR para detección del VBIA.

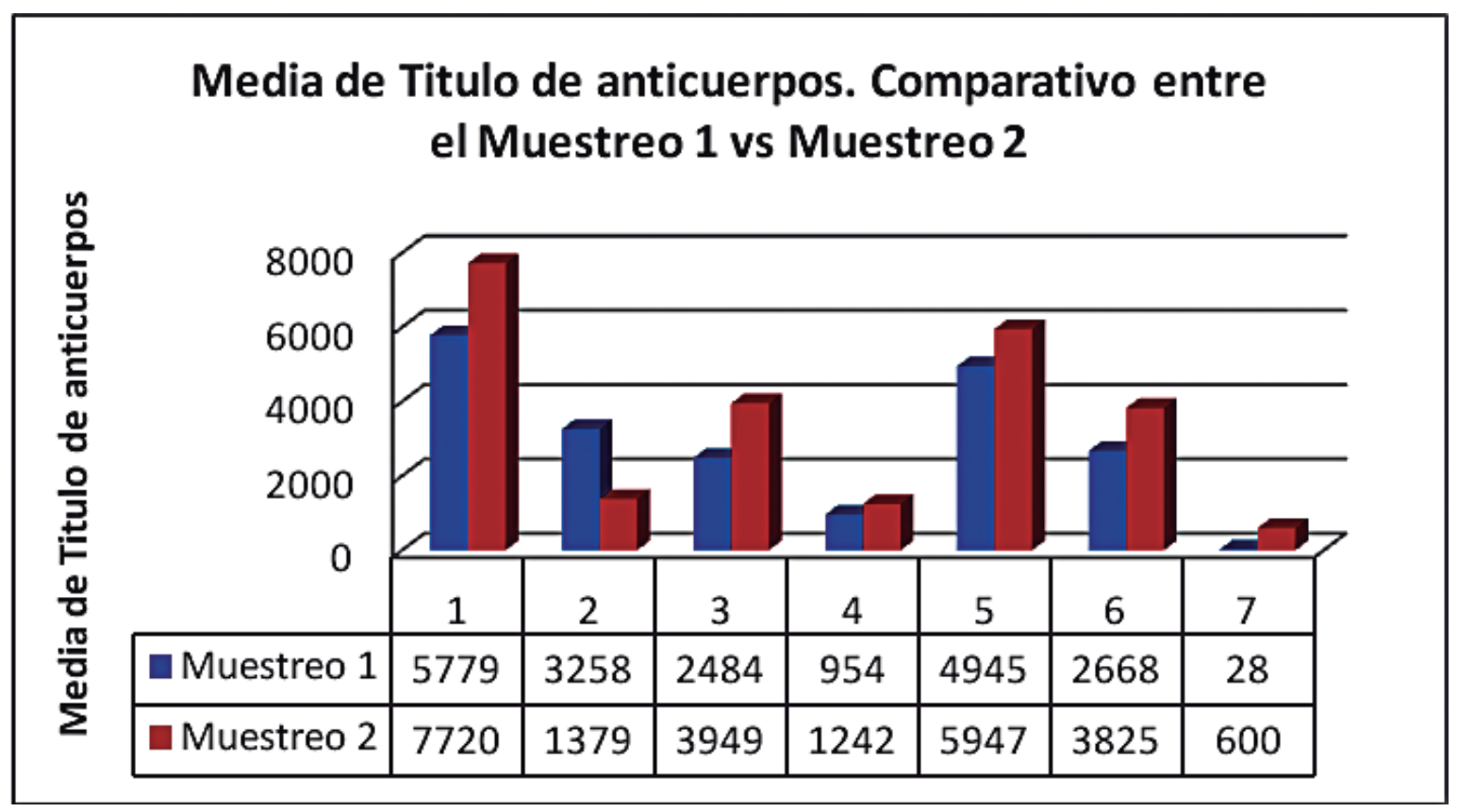

Gráfica 1. Dinámica de títulos de anticuerpos. Comparativo entre el muestreo 1 y muestreo 2 de cada una de las granjas.

Los antecedentes de las granjas se evidenciaron al momento del muestreo, en el cual el 100\% de los predios escogidos presentaba histórico o antecedentes de problemas respiratorios y en el momento de la toma del primer muestreo las aves se encontraban con algún tipo de sintomatología respiratoria como estornudos, presencia de moco, estertores, problemas de lotes disparejos o cualquier otra sintomatología asociada a problemas respiratorios. Ninguna de las granjas evaluadas contaba con línea base de perfiles serológicos que permitiera establecer un estatus serológico inicial.

Al revisar los resultados obtenidos en cada uno de los grupos de las granjas procesadas se obtuvo la siguiente información:

En la granja No. $1 \mathrm{SL}$, las aves habían recibido 5 dosis de vacuna viva de virus de BIA previo al primer muestreo y una sexta dosis antes del segundo muestreo. La última vacunación se realizó a la semana 26 de edad, y el primer muestreo se realizó a la semana 33 de edad. Como resultado del primer muestreo se observó un promedio de títulos de 5.779 y para el segundo muestreo a los 20 días de 7.720, con un CV\% (Coeficiente de variación) de $45.6 \%$ y $44 \%$ respectivamente. Los resultados de la prueba estadística arrojan significancia estadística, indicando exposición al virus de campo positiva, con un CV alto, superior al $30 \%$. El análisis a través de la prueba de RT-PCR arrojó resultados positivos, para los órganos de tráquea y riñón. De igual manera se resalta que al momento de toma del primer muestreo las aves presentaban ruido respiratorio y descarga nasal, Figura 2. Los pollos infectados mostraban un exudado seroso, catarral o caseoso en tráquea. En el histograma de la Gráfica 2 se observa el desplazamiento de las columnas hacia la derecha. 


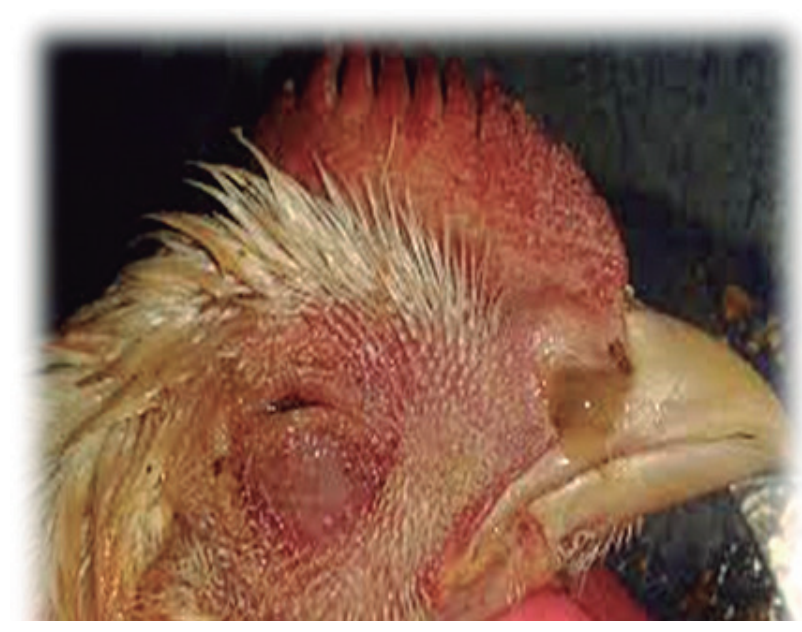

Figura 2. Secreciones nasales mucopurulentas

En la granja No. 2 L1, las aves fueron vacunadas al día 15 de edad correspondiendo a la segunda dosis en su plan vacunal, el muestreo fue realizado el día 17 de edad. El resultado de títulos de anticuerpos del primer muestreo fue de 3258 con un $77.4 \%$ de CV y como resultado del segundo muestreo se obtuvo un promedio de título de anticuerpos de 1359 con un $91.5 \%$ de CV. Estadísticamente los resultados son significativos para el primer muestreo. Al momento del mues-

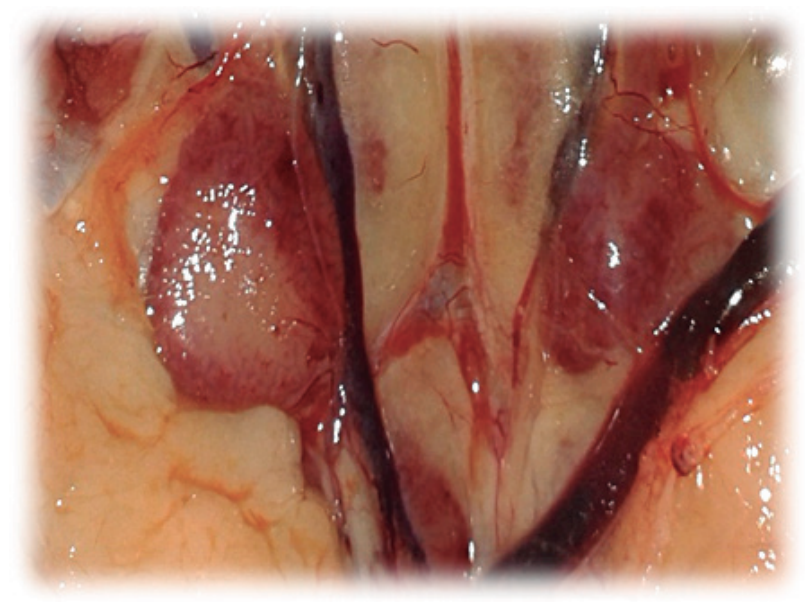

Figura 3. Riñones aumentados de tamaño.

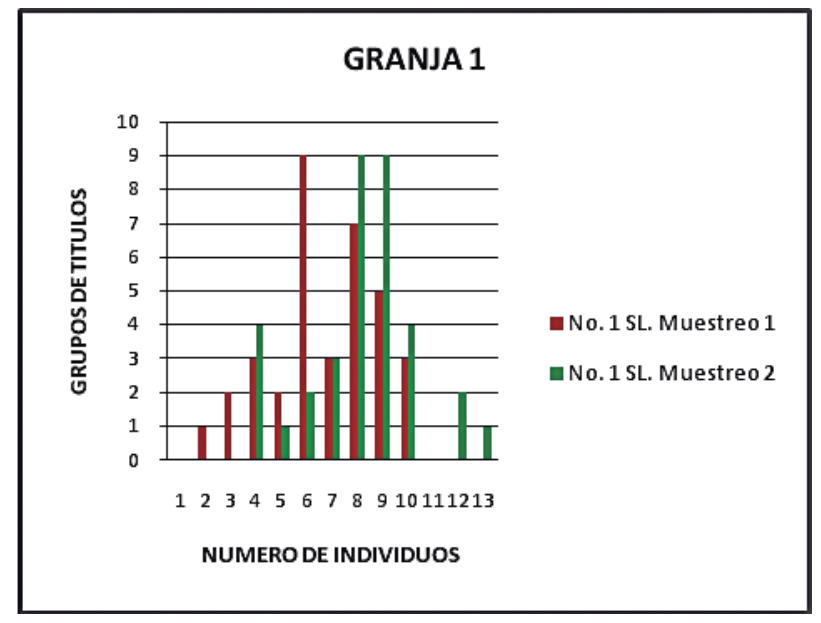

Gráfica 2. Comportamiento de anticuerpos comparados entre el primer y segundo muestreo de la granja No. 1 SL

treo el lote presentaba ruidos respiratorios, estornudos, apilamientos de las aves, y a la necropsia se evidenció la presencia de tráquea congestionada, riñones aumentados de tamaño, Figura 3 y material fibrinoso en sacos aéreos. Al realizar las pruebas complementarias de HA y RT-PCR a partir de los órganos aislados se obtuvo resultados positivos en RT-PCR y HA para la muestra de riñones. La Gráfica 3, muestra un comportamiento de anticuerpos con desplazamiento hacia la izquierda.

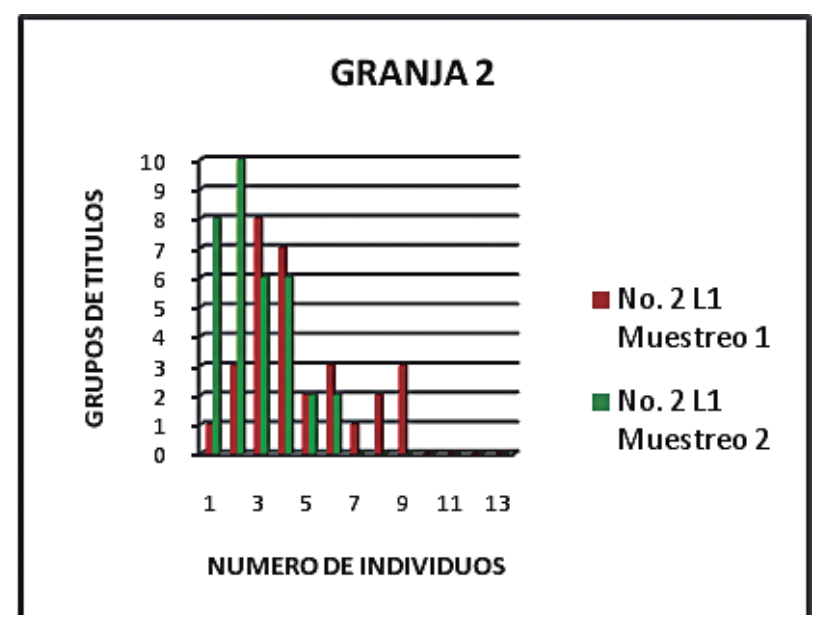

Gráfica 3. Comportamiento de anticuerpos comparados entre el primer y segundo muestreo de la granja No. 2 LS. 
Las granjas No. 3, 5 y 6, fueron agrupadas dada la similitud del comportamiento en sus resultados. La granja 3 (SR) recibió una única dosis vacunal al día 14 de edad y fue muestreada el día 29 de edad. Se obtuvieron resultados de títulos de anticuerpos para el muestreo 1 de 2484 con un $149.2 \%$ de CV y para el muestreo 2 se obtuvo un titulo de anticuerpos de 3949 con un $48.6 \%$ de CV. La granja No. 5 PN, fue muestreada a los 16 días de edad, con previa vacunación al día 6 y una segunda dosis al día 15 de edad. Los resultados de títulos de anticuerpos obtenidos fueron de 4945 y de 5947

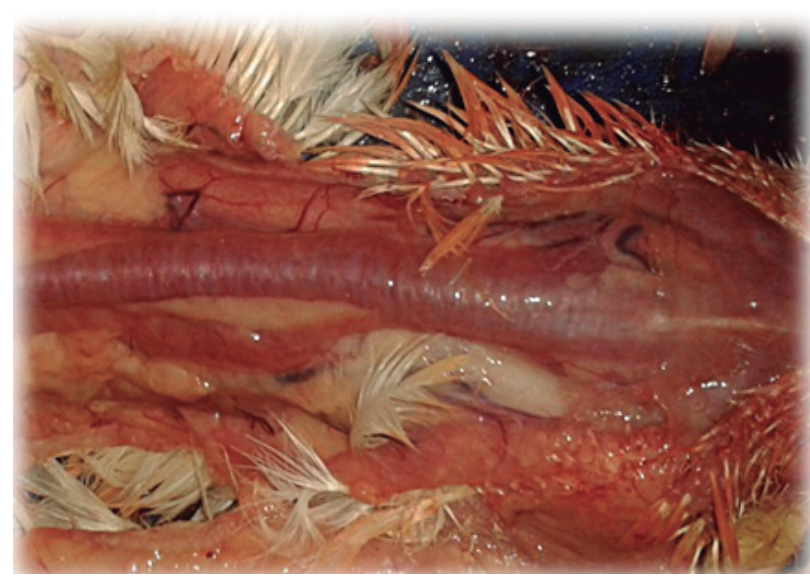

Figura 4. Tráquea congestionada.Or immodienia popubli ame

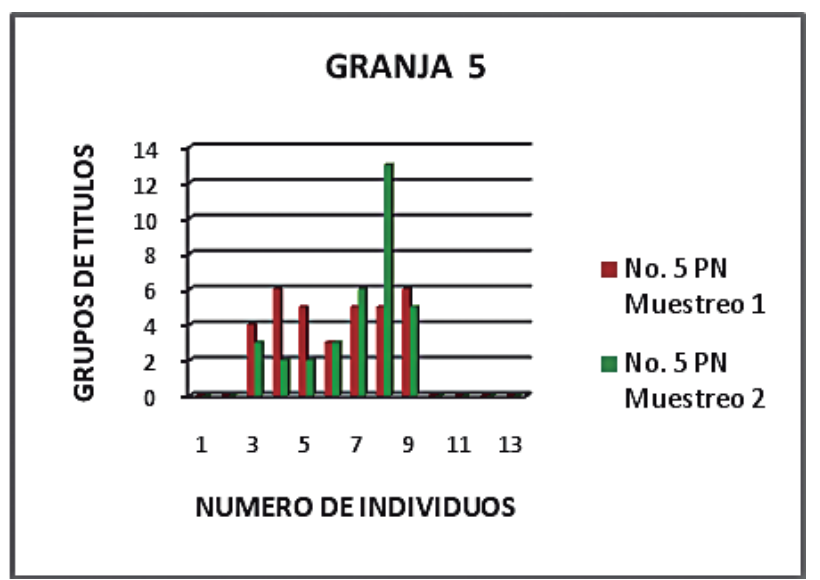

Gráfica 5. Comportamiento de anticuerpos comparados entre el primer y segundo muestreo de la granja No. 5. PN. para el muestreo 1 y 2 , con un $\% \mathrm{CV}$ de $48.9 \%$ y 39.7\% respectivamente. La granja No. 6 BQ, fue muestreada inicialmente a los 17 días de edad de las aves, posterior a ser vacunadas al día 5 de edad. Las pruebas arrojaron resultados de títulos de anticuerpos para VBIA de 2668 con un CV de $62.4 \%$ en el muestreo 1 y 3725 con un CV de $47.7 \%$ en el muestreo 2. Las pruebas estadísticas definieron significancia estadística a la actividad por virus de BIA. Al realizar la prueba de HA, y RT-PCR se obtuvieron resultados positivos para tráquea y riñón.

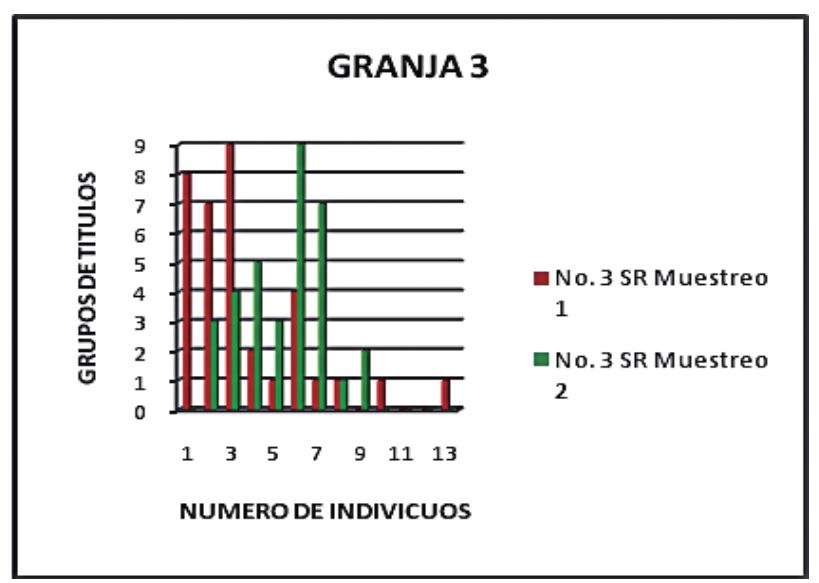

Gráfica 4. Comportamiento de anticuerpos comparados entre el primer y segundo muestreo de la granja No. 3 SR.

\section{GRANJA 6}

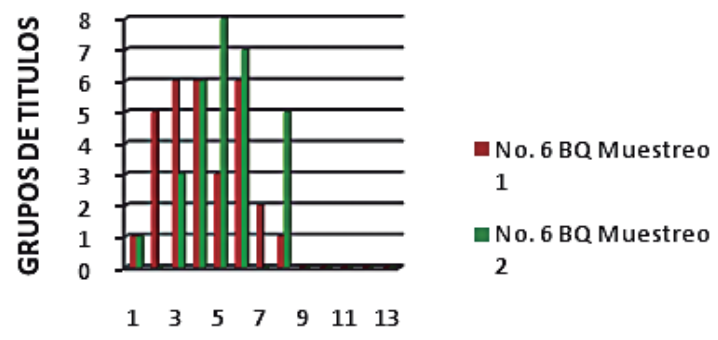

NUMERO DE INDIVIDUOS

Gráfica 6. Comportamiento de anticuerpos comparados entre el primer y segundo muestreo en granja No. 6. BQ. 
A la inspección macroscópica se observó la presencia de rińones y tráquea congestionada, $\mathrm{Fi}$ gura 4 y 5 , sacos aéreos con contenido de caseificación, y pericarditis fibrinopurulenta.

En la granja No. 4 DN, al momento del muestreo las aves tenían una edad de 23 días y habían sido vacunadas al día seis y 16 de edad. Los resultados de anticuerpos para el muestreo 1 fueron de 954 y para el muestreo 2 de 1242 , a su vez con un $124.3 \%$ y $76.4 \%$ de CV respectivamente, observando una alta dispersión de títulos. Se destaca la situación sanitaria del lote de producción al momento del muestreo, ya que

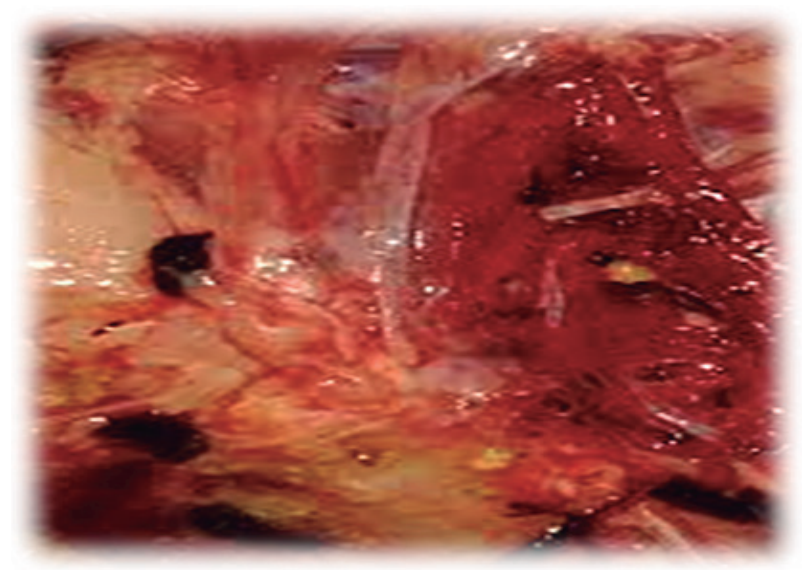

Figura 5. Pulmones congestionados.

Finalmente para la granja 7 SC, las aves fueron muestreadas a los 20 días de edad, las cuales contaban con una única dosis de vacunación a los 5 días de edad. Los resultados de nivel de títulos de anticuerpos fue de 28 en el primer muestreo y de 600 para el segundo muestreo, con un porcentaje de CV de $161.6 \%$ y $213.7 \%$ respectivamente. Adicionalmente se asocia el hecho de que en la granja se encontraban aves con presencia de mucosas congestionadas y secreciones oculares, Figura se observa un lote disparejo, con gran parte de la población con presencia de dificultad respiratoria y un peso por debajo del normal de acuerdo a su edad. De igual manera en la Gráfica 5, se observa dispersión de anticuerpos habiendo desplazamiento de la población hacia agrupaciones con presencia de títulos de anticuerpos más altos comparado con el primer muestreo. Se confirma la actividad viral del VBIA a través de resultado de RT-PCR en donde se confirma la presencia del virus para las muestras de pulmón, e hisopos traqueales. Las pruebas estadísticas demuestran significancia estadística para exposición al virus de campo.

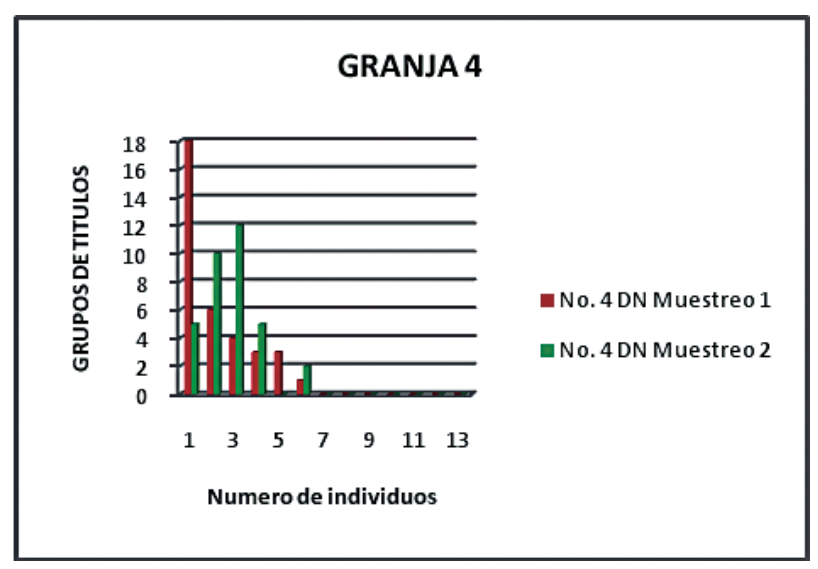

Gráfica 7. Comportamiento de anticuerpos comparados entre el primer y segundo muestreo de la granja No. $4 \mathrm{DN}$.

6, al igual que los resultados paralelos obtenidos de HA positiva para tráquea, pulmón e hisopos y RT-PCR positiva para hisopos traqueales.

Como se mencionó previamente, los antecedentes de las granjas se evidenciaron al momento del muestreo, en el cual el $100 \%$ de los predios escogidos presentaban histórico o antecedentes de problemas respiratorios y en el momento de la toma del primer muestreo las aves se encontraban con algún tipo de 


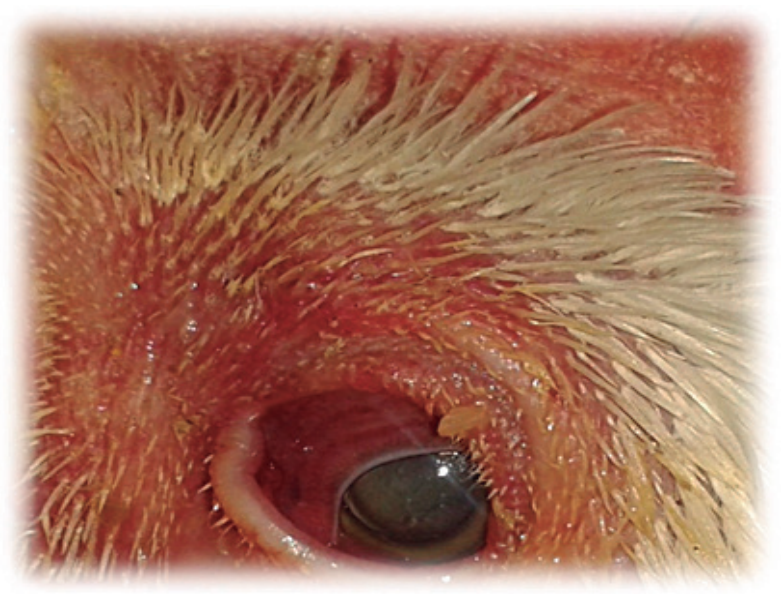

Figura 6. Congestión de mucosa ocular y cabeza hinchada.

sintomatología respiratoria como estornudos, presencia de moco, estertores, problemas de lotes disparejos o cualquier otra sintomatología asociada a problemas respiratorios. Ninguna de las granjas muestreadas contaban con línea base de perfiles serológicos que permitiera establecer un estatus serológico inicial.

\section{Discusión}

Al analizar los resultados obtenidos de acuerdo al principio aplicado por la prueba de ELISA, se tuvo en cuenta la asociación con las características propias de cada granja en cuanto al plan vacunal y estado de salud presentado al momento de la toma de las muestras. El tiempo transcurrido entre la última dosis de vacuna recibida por las aves asociado al proceso de presentación de cuadro respiratorio al igual que el momento en que se tomaron las muestras para las pruebas, son un factor fundamental a la hora de establecer el análisis de las lecturas obtenidas.

Tener en cuenta el \% CV en los resultados serológicos resulta de gran importancia ya que permite establecer la homogeneidad de la respuesta a los planes vacunales o de la actividad del agente viral, como también permite evidenciar la distribución de los grupos de títulos dejando evidenciar posibles brotes de campo en las parvadas (26).

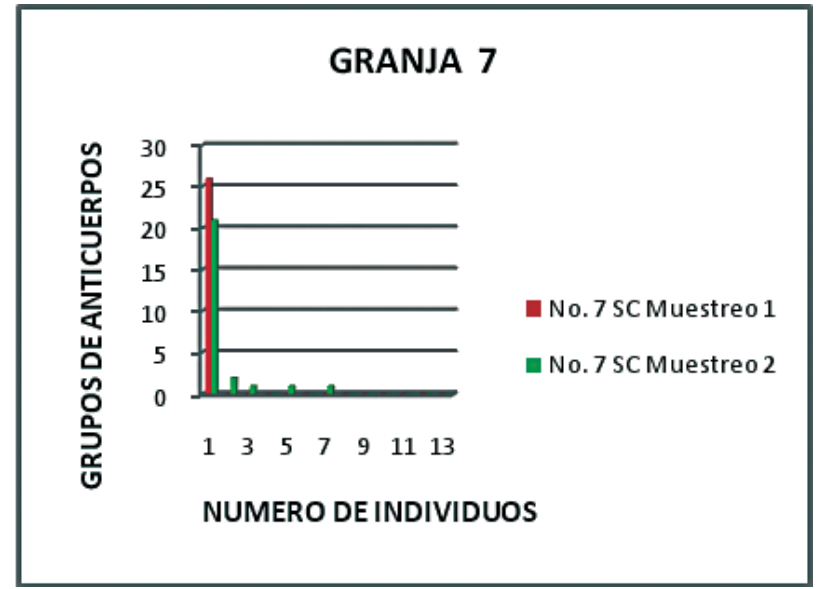

Gráfica 8. Comportamiento de anticuerpos comparados entre el primer y segundo muestreo de la granja No. 7.SC.

Aunque existen unos parámetros como guía referencia para la interpretación de resultados obtenidos en la prueba de Elisa, diferentes autores realizan reportes de estudios como guías de interpretación. En estudios realizados por Swayned, (27), se menciona que para pollo de engorde vacunado con una vacuna de virus vivo se esperan títulos de 500 a 2500 siendo una condición que no daría indicios de una exposición al virus de campo; a su vez en aves ponedoras con 2 o 3 aplicaciones de vacunas de virus vivos se pueden obtener títulos hasta de 10.000 como condición normal.

En otros reportes se hace referencia a resultados obtenidos en aves con aplicación de vacunas suaves tipo Mass y que han recibido niveles de desafío bajos en los que se esperarían títulos promedio de hasta 1.000 o menos. Aves con aplicación de vacunas fuertes, y ante niveles de desafío de campo bajos presenta títulos promedio esperados entre 1.000 y 2.500 . Por otra parte en lotes vacunados con vacunas fuertes y ante desafío alto de campo se pueden obtener títulos entre 2.500 y 7.000. En lotes enfrentados ante procesos deficientes de vacunación o a un desafío de campo heterólogo se pueden obtener perfiles de lectura mayores a 7.000, y en situaciones en las que se evidencian aves enfermas coincide con títulos mayores de 6.500 (27). 
En estudios en los que se tiene en cuenta el \%CV, los autores hacen referencia a parámetros como base para la interpretación serológica de la prueba de Elisa entre los que se incluye como complementario el coeficiente de variación dado en porcentaje $(\% \mathrm{CV})$, el cual expresa los porcentajes, la dispersión y distribución de los títulos de anticuerpos contra el virus. Una baja dispersión de títulos (CV inferior a 25\%) se interpreta como ausencia de infección, aún siendo excelente un $\% \mathrm{CV}$ de $30 \%$ o menor, reflejando una buena respuesta a la vacunación y por ende una buena cobertura vacunal. Coeficientes de variación entre $30 \%$ a $50 \%$ se pueden considerar como valores buenos correspondiendo a vacunaciones homogéneas, sin embargo ante brotes de campo indica una dispersión elevada de los títulos de anticuerpos, debido a una infección aguda o procesos crónicos, causada por un virus de campo, en ausencia de vacunación. Un CV mayor del 60\% en una parvada indica que en ella hay aves con muy poca o ninguna respuesta, además de aves con respuesta alta o adecuada a la vacunación y por tanto para fines vacunales es importante revisar los procesos de vacunación y/ó la posibilidad de infección viral (Laboratorios IDEXX) (28).

En la granja No. 1 SL, hay un descenso de los títulos vacunales y se observa que había transcurrido más de 20 días después de la vacunación, lo cual es compatible con lo típicamente esperando dentro del comportamiento de los títulos posteriores a procesos vacunales. $\mathrm{Al}$ obtener $\mathrm{CV} \%$ inicialmente de $45.6 \%$ y seguido de $44 \%$, sugiere actividad viral y de acuerdo a los niveles de anticuerpos observados puede ser compatible con presencia de virus de campo, ya que en aves vacunadas que presentan títulos superiores a 2500 es indicativo de exposición viral diferente a una respuesta vacunal, teniendo como base los parámetros de referencia IDDEX, y de acuerdo a reportes de estudios realizados por Cuello (25) y Levrier (29). La significancia estadística asociada a un CV alto, superior al 30\%, con dispersión de títulos se da en situaciones de presencia de virus de campo, guardando correlación con los niveles de anticuerpos obtenidos, y conforme a los parámetros señalados por Swayne (27). Se destaca la compatibilidad de los resultados positivos de la prueba de HA y RT-PCR que al ser positivas confirman la presencia de actividad viral. La sintomatología presentada corresponde a las descripciones realizadas por Cavanagh (4), (30). El desplazamiento de las columnas hacia la derecha indica la actividad de anticuerpos de manera comparativa entre el primero y el segundo muestreo que se da conforme avanza el desarrollo de la enfermedad y de acuerdo a estudios reportados por Noda (16), es un comportamiento típico de la presentación de virus de campo. La presencia de virus de BIA detectada a través de la prueba de RT-PCR confirma la actividad viral en granja.

En la granja No. 2 L1, la actividad de anticuerpos indica incremento del nivel de éstos, que sobrepasa los límites esperados para aves vacunadas bajo las condiciones descritas, al estar éste valor sobrepasando el límite de títulos de 2000, (24), que al asociarlo con un CV de $77.4 \%$ permite considerar la presencia de actividad de virus de campo (16), ya que se traduce en una alta dispersión de presencia de anticuerpos que se da en procesos de desafío de virus de campo o proceso vacunal desuniforme (IDEXX, 30). Las lesiones identificadas asociadas con la sintomatología corresponden a las descritas por Saif (30), respaldando los indicios de éstas frente a actividad viral. La alta dispersión de títulos de anticuerpos identificada es una situación que comúnmente se presenta en procesos de baja respuesta vacunal. Se muestra una alta relación con un desafío por virus de campo dados los resultados obtenidos conforme a interpretaciones reportadas por Noda (16). El comportamiento de anticuerpos con desplazamiento hacia la izquierda es evidencia de heterogeneidad, de acuerdo a las líneas de análisis realizadas por D’Wit, (25), siendo correspondiente al descenso de los títulos de anticuerpos. La presencia de actividad viral se logra corroborar a través de los resultados de aislamientos virales y de las pruebas de RT-PCR.

En las granjas No. 3, 5 y 6, los signos y lesiones macroscópicas observadas en las aves son compatibles con lesiones ocasionadas por presencia del virus de BIA de acuerdo a reportes de diferentes autores (31). 
En éstas granjas al revisar el \%CV indica desuniformidad en la distribución de los anticuerpos, a la vez que adicionalmente el nivel de anticuerpos sobrepasa el mínimo esperado para aves vacunadas (superior a 2000), esto puede indicar una posible exposición a virus de campo.

La presencia de un ascenso de los títulos se genera ante una exposición viral; en condiciones normales se esperaría un descenso en los anticuerpos presentes, adicionalmente el \%CV obtenido es propio de un comportamiento de infección por virus de campo, de acuerdo a los parámetros planteados por los autores, con una respuesta generalizada por parte del lote de acuerdo al análisis reportado por Gelb J. (31), Mockett (32). Al observar las gráficas de los histogramas y de acuerdo a los planteamientos de interpretación reportados por Noda (16), se puede observar la dispersión de los anticuerpos de resultados obtenidos del primero y segundo muestreo, lo cual se observa en situaciones de infecciones por virus de campo (Gráfica No. 4, 5 y 6). Los resultados obtenidos en la prueba de RT-PCR demostraron la presencia del virus de BIA. En los histogramas se observa que la actividad se mantiene, no muestra un desplazamiento notorio hacia la izquierda, sin embargo no se observa disminución en la distribución demostrando que la actividad viral se mantiene; cabe notar que en cuanto a la distribución de individuos en las diferentes categorías de rangos de grupos hay un incremento de ubicación de individuos hacia rangos más altos de títulos virales. Gráficas 6 y 7.

En la granja No. 4 DN, Los valores de CV\% obtenidos reflejan alta dispersión de títulos lo cual es compatible en situaciones de desafío de campo o pobre protección vacunal, de acuerdo a los parámetros de lectura planteados. Al observar los resultados del siguiente muestreo se evidencia un incremento en los valores de anticuerpos obtenidos y un CV inferior, sin embargo los títulos obtenidos no sobrepasan los límites superiores, lo que permite concluir que no corresponde a una respuesta propia de exposición al virus de campo, por otra parte un alto CV\% es un indicativo que conlleva a asociar un proceso de desarrollo de anticuerpos ante un virus de campo o procesos vacunales deficientes de acuerdo a líneas base de análisis planteadas por Gelb, (31) y por el fabricante del kit IDEXX. Dado que el nivel de anticuerpos desarrollados no sobrepasa el límite esperado se puede pensar en una baja protección en los procesos vacunales, sin embargo a la vez al existir una baja protección se puede pensar en un proceso de susceptibilidad ante agentes de campo. La situación sanitaria y lesiones identificadas corresponden a reportes realizados por Cavanagh (4) y (10). La dispersión de anticuerpos identificada con desplazamiento hacia agrupaciones con presencia de títulos de anticuerpos más altos son compatibles con problemas relacionados con virus de campo de acuerdo a la tendencia que se presenta, guardando correlación con los resultados positivos al aislamiento del virus obtenido y por RT-PCR.

Finalmente, para la granja 7 SC se puede observar que los títulos de anticuerpos se conservan en un rango bajo, mostrando exposición negativa hacia el virus de campo, (valores de titulo de anticuerpos se encuentran por debajo de 2000) a pesar de que se cuenta con CV altos, la distribución de los títulos se encuentra entre los grupos de 0 a 1000. En este caso, dado el CV alto podría corresponder a una respuesta heterogénea a un desafío de antígeno que se da en aves con procesos vacunales de pobre cobertura (29). De acuerdo a los parámetros de interpretación de lectura de resultados sugeridos por IDEXX y estudios realizados y reportados por diferentes autores, se resalta situaciones en las que no se vacunan las aves en su totalidad, y la exposición temprana al agente puede producir resultados de éste perfil. Al observar el comportamiento del histograma (gráfica 8), que representa los títulos agrupados hacia un pobre desarrollo de anticuerpos evidencia una mala respuesta como resultado posiblemente de una inadecuada vacunación. De acuerdo a las líneas base referidas en estudios de Witt (25) en donde llevan a deducir que la baja protección y \% de CV desuniforme se puede tratar de un caso en el que se cuente con una baja protección vacunal; los recuentos bajos de anticuerpos la pueden clasificar como negativa para respuesta 
al virus de BIA. Sin embargo, los resultados obtenidos en la prueba de RT-PCR demostraron la presencia del VBIA. A pesar de que las pruebas estadísticas reportan significancia estadística negativa indicando que no hay actividad viral, la presencia de niveles de anticuerpos altos en algunas aves sugiere que puede haber circulación del agente

En conclusión, se puede observar que de un total de 7 granjas, 6 presentaron incrementos de niveles de anticuerpos con valores superiores a los establecidos a partir de las líneas base de análisis sugiriendo algún tipo de actividad viral por el virus de BIA, correspondiendo a un valor de $85.71 \%$ de granjas con actividad viral.

A nivel práctico en campo, los criterios que se tienen en cuenta para el establecimiento de medidas de acción hacia un problema respiratorio detectado se basan en la sintomatología, siendo un punto de partida para el establecimiento del plan vacunal en la parvada. En las situaciones en que se decide realizar pruebas de Elisa como base diagnóstica se puede dar la situación que se realice durante el momento en que se evidencian los síntomas respiratorios, caso en el cual no se espera encontrar títulos altos de anticuerpos dado que el pico del desarrollo de anticuerpos se presenta días después de la exposición al virus, por tanto al no conocer este aspecto se puede interpretar erróneamente los resultados de la prueba, considerándose negativa al el virus de BIA.

En cuanto al nivel de anticuerpos producidos como resultado de la vacunación, en donde típicamente se observa un incremento, sin embargo estos títulos son inferiores a los desarrollados ante el desafío de un virus de campo, por tanto es importante la implementación de sistemas que permitan establecer perfiles serológicos para evaluar el comportamiento real del virus en la explotación, por otra parte el nivel de anticuerpos vacunales va ligado al programa de vacunación instaurado. Adicionalmente en las granjas que se sugiere actividad viral de campo, se observa que sobrepasan el límite mínimo esperado en casos de aves vacunadas, y por ende rompen la barrera de protección ante desafíos de campo, lo cual sugiere que la protección conferida a través de los programas vacunales no es suficiente ante la presencia de desafíos de campo, ya sea por deficiencia en los planes o por la presencia de actividad viral en campo de cepas diferentes a las empleadas en las vacunaciones y que a partir de las cepas vacunales no se genera protección cruzada hacia otras posibles cepas ya sean nuevas o variantes.

Es clara la importancia de contar para cada una de las granjas con los datos de líneas base, las cuales deben acoger como primera medida el establecimiento del título de anticuerpos maternos con los que ingresa el pollito a la granja, y que permita establecer el estatus inmune y la dinámica real de los anticuerpos en cada una de las etapas del desarrollo del pollo y de esta manera al realizar los chequeos serológicos se pueda determinar hasta donde los resultados obtenidos corresponden a un comportamiento esperado o realmente hay actividad viral de campo, ya que cada granja se encuentra enfrentada a un estatus sanitario único. Para el establecimiento de las líneas base se sugiere realizar seguimientos para pollo de engorde a los días 1 y 42, para ponedoras al día 1 , semana 4 y 8, antes del pico de postura y 18 semanas, por lo menos, sin embargo estos esquemas estarán sujetos al programa de vacunación implementado $(33,34)$.

Al analizar el \%CV es importante partir de una base en la que en los procesos vacunales están bien establecidos en los cuales se esperaría \%CV idealmente hasta un $40 \%$ de acuerdo a los parámetros de interpretación señalados por laboratorio IDEXX, y demás autores citados, indicando procesos normales, sin embargo un CV alto muestra alta dispersión lo cual normalmente podría estar asociado a procesos causados por virus de campo o ser atribuido a que no todas las aves han sido vacunadas adecuadamente, o a una transferencia de anticuerpos maternos de manera desuniforme lo cual se detecta a edad temprana, o a la exposición temprana al agente infeccioso $(26,32)$. 
Entre los diferentes tipos de respuestas serológicas a lo largo del análisis de las granjas, se observó un tipo de respuesta conocida como "Respuesta serológica Bimodal", que se refiere a una respuesta anormal de títulos, típico de una respuesta de desafío de campo con un \%CV alto, ya que se trata de un comportamiento de distribución no uniforme de los títulos de los anticuerpos, lo que no ocurre si se compara con una respuesta de títulos bajo en una situación normal acompańada por un CV de $40 \%$ o menor.

La presentación de signos clínicos respiratorios ya sea en el momento o como antecedente histórico fue un factor determinante para la escogencia de la granja y lote a muestrear, ya que al ser granjas con actividad clínica y sin vacunaciones posteriores al muestreo No. 1, brinda la posibilidad de que exista algún grado de actividad viral debida a la presencia de virus de campo. Se han reportado signos clínicos como ronquera, y ruidos respiratorios, los cuales son observados a partir del primer día después del desafío, en lotes de aves sin óptima protección vacunal, éstos signos se presentan de manera más severa y tienden a incrementar los títulos de anticuerpos $(35,36)$. Al realizar una correlación entre los títulos de anticuerpos, signos clínicos, lesiones macroscópicas de los diferentes órganos afectados, el desarrollo productivo, y su asociación a resultados de RT-PCR, se podría indicar que los niveles de anticuerpos no siempre guardarán una relación directa con la ausencia de signos clínicos y las lesiones en pollos desafiados con el virus de BIA, sin embargo es una herramienta valiosa para detección de actividad viral bajo planes acertados de seguimiento .

A pesar que la prueba de Elisa como herramienta diagnóstica, permite confirmar un diagnóstico basado en un cuadro clínico y realizar el seguimiento de vacunaciones y resultados de homogeneidad, es indispensable emplear herramientas diagnósticas adicionales tales como RT-PCR, con el fin de identificar cepas actuantes en campo que no son identificadas a través de otras técnicas.
Finalmente es importante resaltar la importancia del uso de programas de vacunación apropiados y de medidas de bioseguridad, para conocer la actividad y el comportamiento esperado de títulos de anticuerpos y así lograr interpretaciones acertadas y dirigidas hacia la identificación de virus de campo actuantes o el estatus inmunitario como resultado de la aplicación de cepas vacunales, al igual que el establecimiento de programas preventivos.

De acuerdo a los resultados obtenidos en el presente trabajo, es pertinente resaltar la importancia de realizar monitoreos asociados a toma de muestras de tejidos con el fin de realizar aislamientos virales que permitan su identificación y caracterización y por tanto obtener resultados que permitan la correlación de los mismos, de igual manera el establecimiento de las líneas base de estatus inmunitario es fundamental para evaluar la actividad de virus de campo o cepas vacunales.

\section{Agradecimientos}

A las empresas avícolas que abrieron sus puertas en sus explotaciones de producción avícola, a AMEVEA por el apoyo en el desarrollo del presente estudio, al Laboratorio de Virología del programa de Post grados de la Facultad de Medicina Veterinaria y de Zootecnia de la Universidad Nacional de Colombia, por su colaboración académica, técnica y científica para el desarrollo del trabajo.

\section{Bibliografía}

1. Moreno O, Díaz J, Determinación serológica para enfermedades de Newcastle y bronquitis infecciosa en las aves de combate de Bucaramanga. Spei Domus. Universidad Cooperativa de Colombia. 2005 Marzo. 1 (1): 29-35.

2. Gutiérrez R, Ramírez G, Camara E, Estudio serológico de bronquitis infecciosa con el virus SIN6, YUC, MEX/96 en aves de traspatio en 30 comunidades de Yucatán. Veterinaria Mexico. 2002 abril-junio. 33 (2):101-107.

3. Cavanagh D, Naqi S, Infectious Bronchitis. Disease of poultry. 11 edition. Iowa State Press. Editorial Board for the American Association of avian pathologist. 2003. 101-119p.

4. Cavanagh D, Coronaviruses in poultry and others birds. Avian Pathology. 2005. 34: 439-448. 
5. Liu HJ, Lee LH, Development of an ELISA for detection of antibodies to avian infectious bronchitis in chickens. Journal of Virology Methods. 2005. 102: 129-138.

6. Jackwood M, Review of Infectious Bronchitis Virus Around the World. Avian Diseases. 2012 December. 56 (4): 634-641.

7. Ignjatovic J, Sapats S, Avian infectious Bronchitis Virus. Rev. Sci. Tech. 2000. 19(2): 493-508.

8. Huang Y, Lee H, Cheng M, Wang Ch, S1 and N gene analysis of avian infectious bronchitis viruses in Taiwan. Avian dis. 2004.48:581-89.

9. Jove M, Evaluación de las cepas H120 y M48 en programas de vacunas contra el virus de Bronquitis infecciosa aviar en aves de carne. [Tesis de maestría]. Lima - Perú. Universidad Nacional Mayor de San Marcos. 2004.

10. Cavanagh D, Survey acute respiratory syndrome vaccine development. Experience of vaccination. Avian Phatology, 2003. 32(6): 567-582.

11. Whiteman C, Bickford A, Bronquitis Infecciosa. Manual de enfermedades de las aves. 2 edition. Pennsylvania. EUA. Asociación americana de patólogos aviares. 1983. 34-38p.

12. Naqi S, Thompson G, Rauman R, Mohammed H, The exacerbating effect of infectious bronchitis virus infection on the infectious bursal disease virus induced suppression of opsonization by Escherichia coli antibody in chickens. Avian Disease. 2001. 45:52-62.

13. Bru T, Geerlings H, Urniza A, Eficacia y seguridad de la vacuna Poulvac IBQX para la protección de broilers, ponedoras y reproductoras frente al serotipo QX del virus de la bronquitis infecciosa aviar. Zaventem, Belgium. Pfizer European Service Center. Hoge Wei 10, B-1930. 2011.

14. Collingwood A, Toro G, Virus bronquitis infecciosa aviar unido a fase sólida para detección de anticuerpos específicos en pruebas de ELISA. Avances en Ciencias Veterinarias. 1992. 7( 2).

15. Gutiérrez JE, Inmunologia Veterinaria. 3 edition. Texas. Edit. El Manual Moderno. 2010.

16. Noda J, Cuello S, Alfonso P, Bronquitis Infecciosa Aviar: obtención de antígeno y detección de anticuerpos por inhibición de la hemoaglutinación. Revista Cubana de Ciencias Avícolas. 2002. 26: 89-95.

17. OIE. Bronquitis infecciosa aviar. Manual de la OIE sobre animales terrestres. 2004. [Acceso en noviembre de 2008]. Disponible en URL:http:/www.oie.int/esp/normes/Manual/ pdf_es/2.7.06_Bronquitis_infecciosa_aviarpdf (17)

18. Gómez L, Blanco M, Domenech A, Manual de Inmunología Veterinaria. 1 edition. Madrid. Prentice Hall. 2006.

19. Álvarez D, Evaluación prospectiva de la carga viral del virus de bronquitis infecciosa aviar en granjas de pollo de engorde con antecedentes de presencia de la enfermedad. [Tesis de maestría]. Bogotá. Universidad Nacional de Colombia. 2009.

20. D’Witt JJ, Mekkes G, Koch, Detection of specific IgM antibodys to infectious bronchitis virus by an antibody-campture ELISA. Avian Pathology. 1998. 27. 155-160.
21. Chacon J, Nogueira J, Assayag M, Epidemilogical survey and molecular characerization of avian infectious bronchitis virus in Brazil Betwon 2003 and 2009. Avian Patology. 2011. 40(2). 153-162.

22. Astudillo K, Cinética de anticuerpos postvacunales contra Bronquitis Infecciosa mediante la microtécnica de Elisa en aves de postura. [Tesis de maestría]. Ecuador. Politécnico del Ejército Ingeniería de Ciencias Agropecuarias. 2013.

23. D’Witt JJ, Swart JM., Efficacy of infectious bronchitis virus vaccinations in the field: association between the IBV IgM response, protection and vaccine application parameters. Avian Patology. 2010 April. 39(2):123-131.

24. Lucio, M.B. Sistema Inmune e Inmunodepresión en las Aves. Memorias del XX Curso Avimex de Salud y Productividad. Actualidades en Vacunología Aviar. México D.F. Junio 27. 2008.

25. Cuello S, Noda J, Bronquitis infecciosa aviar. Cinética de anticuerpos posvacunales en reproductoras y su transferencia a la progenie. Rev. Salud Animal. 2004. 26(1): $42-47$

26. Vinezza C, Interpretación y uso de exámenes de ELISA en avicultura. Revista Veterinaria REDVET. 2005. 6.

27. Swayne D, Glisson J, Jackwood M, Pearson J, Reed W, A Laboratory Manual for the Isolation and Identification of Avian Pathogens. 4 Edition. Pennsylvania. Kennett Square. American Association of Avian Pathologist. 1998.

28. Díaz J, Ríos H, Determinación serológica para las enfermedades de New Casttle y Bronquitis Infecciosa en las aves de combate en Bucaramanga. Spei Domus. 2005 Marzo. 1(1). 29-38.

29. Levrier B. El examen vírico desde el examen clínico al Test - Elisa. L. Aviculteur. Universidad Autónoma de Barcelona Selecciones Avícolas. 1993. 547: 143-149.

30. Saif Y, Fadly AM, Disease of Poultry. Twelfht editors. Iowa USA. Editor in Chief. Asociate editors. 2008. 318-331.

31. Gelb J, Jackwood M, Infectious Bronchitis. Laboratory Manual for the isolation and identification of avian pathogens. Fourth edition. Pennsylvania. 1998. 169-173p.

32. Mockett A, Cook J, The detection of especifi IgM to infectious bronchitis virus in chicken serum using an ELISA. Avian Pathology. 1986. 15:437 - 44p.

33. Cook, J. Serotipos de bronquitis infecciosa y la protección cruzada entre ellos. Curso de enfermedades respiratorias de las aves. ANECA. México. D.F. 1999.

34. Cuello S, Elisa: Desarrollo y estandarización para la detección de anticuerpos de Bronquitis Infecciosa Aviar. Centro de sanidad agropecuaria 2000. (CENSA). Cuba.

35. Yu L, Characterization of three infectious Bronchitis virus isolates from China associated with proventriculus in vaccinated chickens. Avian diseases. 2001. 45: 416-424.

36. Cuello S, Noda J, Alfonso P, Estandarización de un ELISA para la detección de anticuerpos de Bronquitis infecciosa Aviar. Revista Salud Animal. 2006. 2: 131-136.

37. Vitae, Un nuevo Coronavirus es el causante de la neumonía atípica. Academía Biomédica Digital. 2003. Abril - Junio. 